(C) 2018. This manuscript version is made available under the CC-BY-NC-ND 4.0 license http:// creativecommons.org/licenses/by-nc-nd/4.0/ 


\title{
Capabilities of PR professionals for key activities lag: Asia- Pacific study shows theory and practice gaps
}

\author{
Jim Macnamara \\ University of Technology Sydney \\ Ansgar Zerfass \\ University of Leipzig, Germany
}

Ana Adi

Quadriga University of Applied Sciences, Berlin

May O. Lwin

Nanyang Technological University, Singapore

\begin{abstract}
A number of studies of the knowledge, skills and abilities (KSAs), competencies and capabilities of public relations and communication professionals have been carried out in the USA, UK and other countries. However, most have not engaged to any significant extent with literature in the human resource development field which specializes in defining and developing these characteristics. Also, few studies to date have related the KSAs, competencies and capabilities of practitioners to the key activities of public relations and communication management required for the future. This article presents findings and analysis from a regional survey conducted in 22 Asia-Pacific countries in 2017/18 that compared, for the first time, the capabilities of practitioners in relation to activities identified as the most important over the next three years. This data, and comparison with equivalent regional surveys in Europe and Latin America, confirm a gap in capabilities in relation to key communication activities and suggest a gap in theory as well as practice. The findings and conclusions present a challenge for higher education and professional development for public relations and communication management and point to potential future directions in theory building.
\end{abstract}

Keywords: Public relations, social media, capabilities, competencies, Asia-Pacific

\section{Introduction}

When asked about knowledge, skills and abilities (referred to as KSAs), competencies, and/or capabilities, the public relations (PR) industry and related fields of professional communication practice most frequently call for and promote basic technical skills to meet immediate needs. For example, a 2015 survey of PR agencies in the United States of America (US) found that writing (92.6 per cent) and "media pitching" (88.9 per cent) were the 'competencies' rated as most important. Research was rated a distant third (59.3 per cent) and this was related to analyzing information, not conducting primary research (Bates, 2015). Similarly, the 2015 State of the Profession survey of more than 2,000 PR practitioners in the United Kingdom (UK) by the Chartered Institute of Public Relations (CIPR) found that " 64 per cent of all PR professionals identify traditional PR skills (written communication, interpersonal skills, etc.) as key competencies when hiring junior and senior candidates ... compared to 20 per cent who identify digital/technical PR skills (e.g., search engine optimization and HTML coding) as key competencies” (CIPR, 2015). The 2017 CIPR State of the Profession survey also found that 
'traditional written communication' continues to be the highest rated requirement in hiring graduates and junior employees (CIPR, 2017, p. 28).

However, like many other workers and managers, PR and communication practitioners increasingly need to adapt to new and rapidly changing environments including 'disruptive change' (AMEC, 2017) that is radically reshaping industries and professions. Studies have suggested that up to 50 per cent of the jobs and occupations that exist today will not exist by 2025 (CBRE, 2015). Conversely, futurists such as Thomas Frey (2014) say that many of the jobs of the future do not exist yet. Therefore, practitioners other than those who plan to retire in the near future need to have capabilities to face new, unfamiliar and unforeseen challenges.

This has resulted in a renewed focus on identifying and developing core capabilities required in a changing world. An underlying premise in examining KSAs, competencies, and capabilities - terminologies that will be explained in this discussion - is that these should not only equip practitioners to undertake the tasks and roles of today, but also equip them to meet the challenges of the future.

In 2014-2015 the Global Alliance for Public Relations and Communication Management (Global Alliance for short) produced a Global Body of Knowledge (GBOK) based on examination of 30 frameworks from around the world and almost 1,000 pages of descriptions of KSAs, competencies, and capabilities related to PR and communication management (Global Alliance, 2015). This was complemented one year later by commencement of a twoyear study to develop a capabilities framework that identifies core capabilities for communication professionals that can be adapted to different cultures, different roles, and different levels. The findings of this latest Global Alliance study released in mid-2018 are summarized in reviewing relevant literature and compared with the findings reported here.

Three fields of literature inform this analysis. First, literature outside of public relations and communication - namely in management studies and human resource development - provides important definitions, models and theories relevant to KSAs, competence, competencies and capabilities. Second, the practices examined here need to be reviewed in the context of public relations and communication management theory. Third, this analysis draws on approaches to theory building in communication studies, which it argues are relevant to public relations and communication management.

\section{The literature on KSAs, competence, competencies and capabilities}

Study of KSAs, competencies, competence, and capabilities for PR and communication practitioners is informed by two bodies of literature. While the disciplinary focus of this discussion suggests a review of public relations and related literature, definitions of these terms and explanation of relevant concepts and principles are provided in human resource (HR) literature $^{1}$, particularly that related to professional development, performance management, and specialist fields such as human performance technology (Teodorescu, 2006). Therefore, analysis of KSAs, competencies and capabilities most productively begins and proceeds with a transdisciplinary focus. After identifying definitions and characteristics of these elements, their application in PR and communication management in informed by review of disciplinary literature that focusses on KSAs, competencies, competence, and capabilities. This is not a large field of study, but it has grown during the past two decades.

\subsection{Knowledge, skills and abilities (KSAs)}

Knowledge, skills, and abilities, commonly abbreviated to KSAs, have been widely applied in government staff recruitment and performance evaluation. For example, the US federal 
administration uses KSAs along with curriculum vitae (CVs) as the basis of selecting candidates for positions. Even though KSA scoring sheets were phased out in 2009, most US federal government departments and agencies continue to place emphasis on KSAs in recruitment and staff development. For instance, the US Department of Veterans Affairs says that "KSAs are used to distinguish the 'qualified candidates' from the 'unqualified candidates' for a position” (Department of Veterans Affairs, 2009, para. 4).

There is a wide range of definitions and descriptions of KSAs. A widely applied definition is that of the US Office of Personnel Management (OPM), which manages the US civil service, On the USA Jobs website, which processes more than one billion government job searches a year, the OPM says:

Knowledge, skills, and abilities (KSAs), or competencies are the attributes required to perform a job and are generally demonstrated through qualifying experience, education, or training. Knowledge is a body of information applied directly to the performance of a function. Skill is an observable competence to perform a learned psychomotor act. Ability is competence to perform an observable behavior or a behavior that results in an observable product. (USA Jobs, 2018, para. 1) [italics added]

The US Department of Veteran Affairs (2009) provides a more detailed description of KSAs as:

Knowledge - an organized body of information, usually factual or procedural in nature. For example, having knowledge of human resources' rules and regulations could be used as a KSA for a human resources specialist position ...

Skill - the proficient manual, verbal, or mental manipulation of data or things. For example, having skill with operating personal computers could be used as a KSA for an office automation position $\ldots$

Ability - the power or capacity to perform an activity or task. For example, having the ability to use a variety of laboratory instruments could be used towards a laboratory technician position. (Department of Veteran Affairs, 2009, para. 3)

KSAs are a focus in many industries and fields of practice (e.g., see Blakiston, 2011; Cetin, Demirçiftçi, \& Bilgihan, 2016; Prestwich \& Ho-Kim, 2007). However, while specific knowledge, skills, and abilities are important, attention in recruitment, professional development, and performance management literature has turned from the micro level to broader concepts.

\subsection{Competencies (or competences)}

As noted on the USA Jobs (2018) website, knowledge, skills, and abilities relevant to a role are collectively referred to as competencies. In some literature, these are also referred to as competences. However, the former term is most common. Specifically, competencies refer to particular sets of KSAs required for a defined role.

\subsection{Competency}

As Teodorescu (2006) notes, in some dictionary definitions, competence and competency seem to "mean basically the same thing" (p. 27). However, in HR literature the two concepts have different origins and, most importantly, denote different approaches.

Competency refers an individual's capacity to perform particular tasks or a role competently. Because it is particularized, competency is usually determined internally within an organization and has been a major focus of HR and performance management in organizations 
over many decades and in HR research (Stevens, 2013). Competency involves a meso-level bottom-up approach that describes what individuals must do to fulfil their roles.

While competency can be modelled to project and predict occupational and individual career paths, studies have found that the effectiveness of competency models is limited. Findings of research highlight the limitations of competency models, particularly because of the influence of contextual factors (Caldwell, 2008).

\subsection{Competence}

More recently, attention has turned to models of competence. Competence is mostly described and defined externally - for example by a professional body. Thus, while competency is an internal approach focused on doing specific tasks and performing certain roles in a particular organization, competence describes the standards required for a role across a sector or an entire occupation or profession. Competence involves a macro-level top-down approach that describes what a field of practice or profession needs for members to fulfil their responsibilities. For example, the International Standards Organization (2012) describes competence as the "ability to apply knowledge and skills to achieve intended results". In Australia, for example, which was included in study, the Public Relations Institute of Australia (PRIA) has developed a professional framework focused on competence, listing expected competencies and a 'competency matrix' (PRIA, 2015).

\subsection{Capabilities}

Most recently, research in human resource management and professional development has advocated focus beyond competencies, competency, and even competence to a broader range of factors that is referred to as the capability or capabilities approach (Gardner, Hase, Gardner, Dunn, \& Carryer, 2008; Hase \& Davis, 1999; Lester, 2014, 2016; O’Connell, Gardner, Coyer, Gardner, \& Coyer, 2014). As well as specific disciplinary studies, the capabilities approach draws on research into international development and sustainability by Nussbaum (2000) and Sen (1999) and recent work on human resource management in the UK by Lester $(1995,2013$, 2014, 2016).

A simple summary is that, while KSAs and competency focus on what practitioners do and competence focusses on needs in a field as determined by a professional or industry body, capability approaches focus on developing potential to achieve or acquire competencies even if they are not present at a particular point in time through certain personal qualities and attributes of individuals as well as ambition and effort (see Figure 1). In this sense, capabilities incorporate generic elements that underpin and enable competencies, such as openmindedness, flexibility, adaptability, and ongoing learning.

Conceptually capabilities constitute a meta-level because they holistically incorporate and integrate KSAs (i.e., competencies), competency and competence. In simple terms, capabilities are made up of competencies, competency, and competence, plus various enablers to go beyond existing knowledge and experience. Nagarajan and Prabhu describe capability as "integration of knowledge, skills, and personal qualities used effectively and appropriately in response to varied, familiar and unfamiliar circumstances” (2015, p. 8). Similarly, Cairns defines capability as "having justified confidence in your ability to take appropriate and effective action to formulate and solve problems in both familiar and unfamiliar and changing settings" (2000, p. 1). Fraser and Greenhalgh are even more specific, describing capability as "the extent to which an individual can apply, adapt, synthesize new knowledge from experience, and continue to improve their performance” (2001, p. 799). 
According to Lester (2014), the capability approach encourages professional maturity because it facilitates more fluid, dynamic engagement with broader issues of professionalism such as the capacity to reflect critically or apply independent judgement in complex situations. Lester also notes that "an advantage of the capability approach is that is generally perceived as an open model, supporting continuous development: there is a spectrum of capability as opposed to either a threshold of 'capable or not capable' or a neat scale of progressively increasing capacity” (Lester, 2014, p. 38). Lester also argues that frameworks focused on competence or competency cannot provide prescriptions for practice that reflect the need for practitioners to act intelligently and ethically and make judgements in complex and unpredictable situations.

Lester has designed a three-level "core capability" model that identifies four main task-related stages, which he describes as "assess”, “decide”, “do”, and "review”, as shown in Figure 1. Within these stages, a number of assessment, decision-making, implementation, and evaluation activities need to be able to be undertaken. Second, Lester identifies that these four task-related stages need to be underpinned by number of managing, communicating, and developing activities including managing work and processes, developing self and others, and communication and client relations. Third, he argues that all activities and tasks must be underpinned by ethics, professionalism, and reflective judgement.

Figure 1. Lester's model for identifying core capabilities (Lester, 2014).

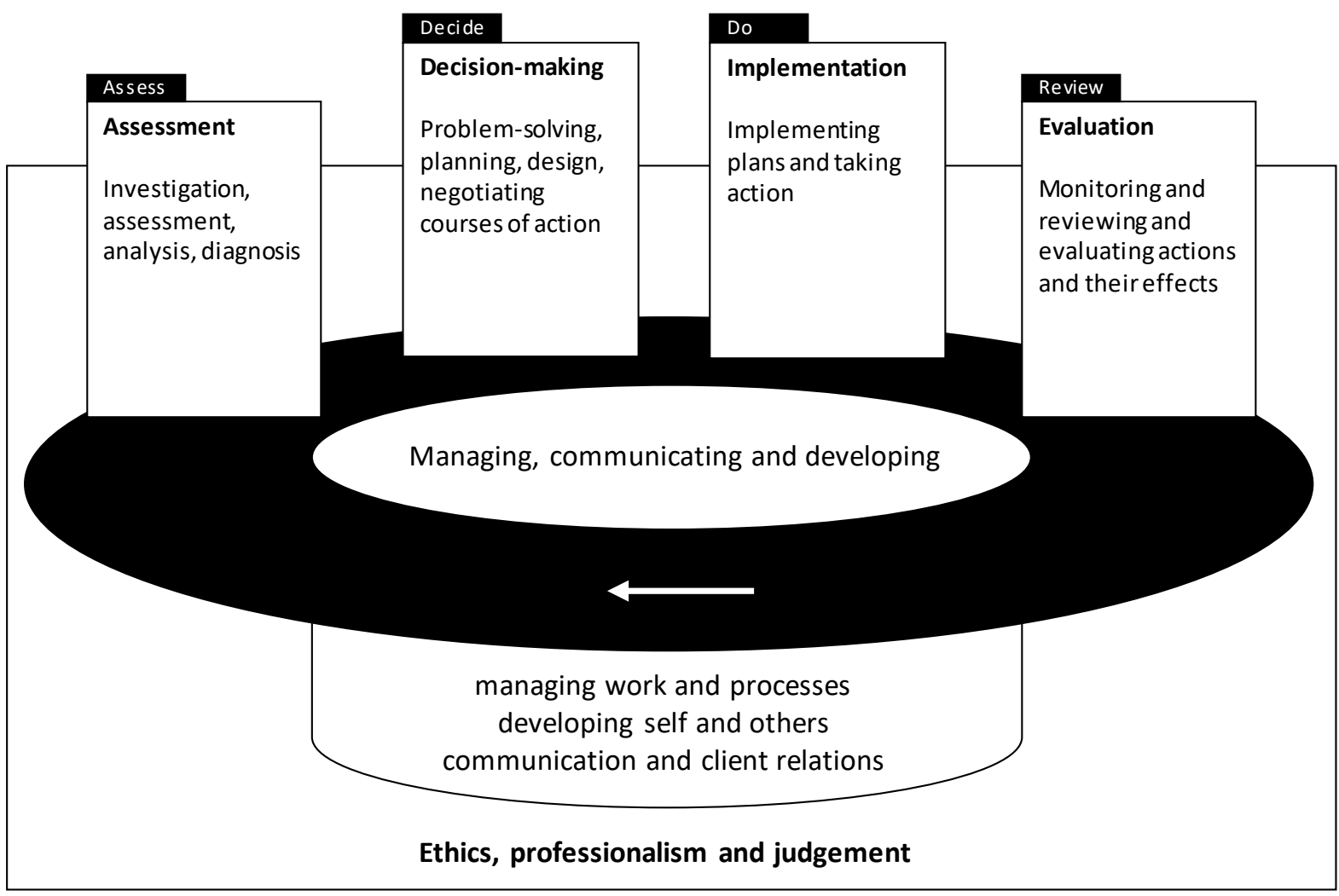

\subsection{Public relations education and professional development}

Within public relations literature, three research studies by the Commission on Public Relations Education (COMPRED) over the past 12 years have identified a range of key skills and capabilities required for public relations practice. The Professional Bond (COMPRED, 2006) reported that critical thinking and problem-solving skills, a good attitude, an ability to communicate publicly, and initiative were essential at entry level. In addition, the report advocated that consideration of ethics, diversity in the workforce, and an understanding of new technologies were important as professionals advanced in their careers. Interestingly, in outlining key subjects for undergraduate and graduate education, The Professional Bond report 
listed public relations theory, but did not include communication theory more broadly. The second report produced by the Commission (COMPRED, 2012) related specifically to the focus and content of postgraduate education programs and recommended similar features but at a more advanced and strategic level. The third COMPRED report released in 2018 identified writing as the most important "core skill”, closely followed by ethics, research, understanding of technology, online learning and knowledge of theory (COMPRED, 2018, pp. 13-16).

The Global Body of Knowledge (GBOK) by the Global Alliance (2015) identified a number of behaviors that are considered important at all levels of experience and seniority. These included: learning; inclusiveness and accommodation; judgement and collaboration; citizenship and sustainability; influence and leadership; ethical conduct; legal and contextual awareness; integrity and accountability; adaptability; and transparency. The GBOK study was considered essential groundwork, but it was identified as not conceptually rigorous because it was drawn from a range of existing literature rather than primary research; it was largely Western in orientation; and it was not considered 'future-proof' because of a focus on 'here and now' needs and priorities.

In 2016 the Global Alliance commenced a further two-year international study with academic partners to develop a capabilities framework that identifies core capabilities for communication professionals and which can be adapted to different cultures, different roles, and different levels using a Delphi survey method "to acquire the most reliable consensus of a group of experts' opinions by a series of intensive questionnaires combined with controlled opinion feedback" (Dalkey \& Helmer,1963, p. 458). The Global Capabilities Framework for the Public Relations and Communication Management Profession released in 2018 identified 11 key communication, organizational and professional capabilities, as shown in Table 1 (Global Alliance, 2018).

Table 1. Key capabilities identified by the Global Alliance (2018).

\begin{tabular}{lll}
\hline Communication & Organizational & Professional \\
\hline $\begin{array}{l}\text { To align communication } \\
\text { strategies with organizational } \\
\text { purpose and values }\end{array}$ & $\begin{array}{l}\text { To facilitate relationships and } \\
\text { build trust with internal and } \\
\text { external stakeholders and } \\
\text { communities }\end{array}$ & $\begin{array}{l}\text { To provide valued counsel and } \\
\text { be a trusted advisor }\end{array}$ \\
\hline $\begin{array}{l}\text { To identify and address } \\
\text { communication problems } \\
\text { proactively }\end{array}$ & $\begin{array}{l}\text { To build and enhance } \\
\text { organizational reputation }\end{array}$ & $\begin{array}{l}\text { To offer organizational } \\
\text { leadership }\end{array}$ \\
\hline $\begin{array}{l}\text { To conduct formative and } \\
\text { evaluative research to } \\
\text { underpin communication } \\
\text { strategies and tactics }\end{array}$ & $\begin{array}{l}\text { To provide contextual } \\
\text { intelligence }\end{array}$ & $\begin{array}{l}\text { To work within an ethical } \\
\text { framework on behalf of the } \\
\text { organization, in line with } \\
\text { professional and societal } \\
\text { expectations }\end{array}$ \\
\hline $\begin{array}{l}\text { To communicate effectively } \\
\text { across a full range of platforms } \\
\text { and technologies }\end{array}$ & & $\begin{array}{l}\text { To develop self and others, } \\
\text { including continuing } \\
\text { professional learning }\end{array}$ \\
\hline
\end{tabular}

\section{Framing within PR and communication management theory}

This analysis is also informed by theories and models of public relations and communication management. It is not necessary or appropriate to review this literature in detail here as it is thoroughly discussed in other places (e.g., Botan \& Hazelton, 2006; Edwards, 2018). However, it is relevant to note that Excellence theory of public relations (L. Grunig, J. Grunig \& Dozier, 2002) and related middle range theories such as co-orientation (Broom \& Dozier, 1990; Verčič, 
2008) emphasize a central focus on two-way interaction, understanding publics, and creating and maintaining relationships.

More recent theories such as dialogic theory of public relations (Kent \& Taylor, 2002; Taylor \& Kent, 2014) and engagement (Johnston, 2014) particularly emphasize two-way interaction aimed at mutuality, including 'conversations' in social media (Kent, 2013), rather than oneway transmission or information and persuasion. Sociocultural approaches to public relations further draw attention to the need to align activities to societal interests as well as organizational interests (Edwards, 2018; Edwards \& Hodges, 2011).

Strategic communication approaches, which are widely promoted in Europe, emphasize alignment of communication objectives and activities with organizational goals and priorities (Holtzhausen \& Zerfass, 2013; Zerfass \& Volk, in print). However, theorists concerned about ethics, societal interests and social responsibility argue that, in addition to serving organizational interests, communication should be ethical (Freeman, 1984) and mutual (Kent \& Taylor, 2002). These theories further provide a framework to inform analysis of the capabilities of practitioners.

\section{Theory and practice - what communication studies tells us}

In an important recent review of communication theory, eminent communication studies scholar Robert Craig argued that communication should be "reconsidered" as a "practical discipline" (2018, p. 289) and he called for the development of practical theory, not only normative theory that prescribes idealized practices. Craig was careful to point out that practical theory is "not merely practical in the colloquial sense of technical or occupational training" (p. 288). Furthermore, practical theory is not simply theory about practice and it is quite distinct from applied theory (Cronen, 2001). In calling for “communicative praxis”, Craig stated:

I will argue that the imperative to improve communication and to disseminate better communication practices is both fundamental to the historical emergence of our discipline and consistent with current trends in the field. (2018, p. 289)

In the same special issue of the Journal of Communication titled 'Ferments in the Field: The Past, Present and Future of Communication Studies', Fuchs and Qiu also drew on Marx's argument for praxis as part of critical thinking and theory building in their call for "transformative praxis that aims at social change towards a better world" (2018, p. 227). Similarly, in a leading contemporary communication theory text, Littlejohn, Foss and Oetzel say that practical theory "goes beyond depiction of how the world is" to "provide a guide to practical action” designed to transform the world (2017, p.14).

This growing body of theory about theory argues that normative theory does not go far enough in informing a field. Given that public relations and communication management are largely informed by and related to communication theory, the same arguments can be applied in critical analysis of these practices. It is therefore relevant in this analysis to ask questions about practices within the context of practical as well as normative theory.

\section{Methodology}

Informed and framed by the preceding transdisciplinary literature review in relation to KSAs, competence, competency and capabilities, the analysis presented in this article is based on empirical data gained from the Asia-Pacific Communication Monitor (APCM), the largest 
survey of PR and communication practitioners in Asia-Pacific, which is conducted biannually in conjunction with the European Communication Monitor and the Latin America Communication Monitor. While using a number of questions common to the Communication Monitor series, regional surveys add additional questions, and the APCM was the first to specifically explore capabilities of practitioners in relation to their major activities and projected priorities for the future.

The 2017/18 Asia-Pacific Communication Monitor (APCM) received complete responses from 1,306 communication practitioners in 22 Asia-Pacific countries ranging from Australia and New Zealand in the south, China and Japan in the north, and India in the west. While it is highly likely that there are substantial differences in practices and stages of industry development across these countries, the sample in this study provides insights into practices and capabilities in a mixture of developed and developing countries and Western and non-Western cultures.

Data from the four sections of the 2017/18 APCM related to (1) practitioners' major activities; (2) perceived strategic issues facing communication management; (3) priorities for the future; and (4) their self-assessed capabilities in relation to their key activities and priorities were cross-tabulated and analyzed to explore the following four research questions.

\subsection{Research questions}

RQ1: What communication activities do PR and communication practitioners consider to be the most important today and looking forward to 2020?

RQ2: What level of skills and capabilities do PR and communication practitioners report having in relation to the communication activities considered most important between now and 2020 ?

RQ3: What level of training and development is available to practitioners for developing skills and capabilities in relation to use of those channels?

RQ4: What are the implications and learnings for researchers, educators, practitioners, and professional industry bodies?

The rationale for the focus of this analysis is that, while capabilities in many areas of activity are important for PR and communication professionals, capabilities related to communication activities considered to be most important over the next three years, and the availability of training and development in relation to those activities, are inarguably high priorities for practitioners and employers, as well as professional industry bodies, educators and researchers and, therefore, deserving of close attention.

\subsection{The instrument}

The online questionnaire used in the 2017/18 study involved 26 questions arranged in 14 sections, three of which are the focus of this analysis as explained above. Design of the instrument was based on research questions and hypotheses explored in the previous biannual study, plus additional issues highlighted in recent industry and academic literature. The questions sought responses on a range of scales, particularly five-point Likert scales graduated from 'very high to 'very low' and 'strongly agree' to 'strongly disagree'.

\subsection{Data collection}

The online survey in English language was hosted on a secure server and accessible through computers, tablets and mobile devices. It was pre-tested in April and May 2017 with communication professionals in 13 Asia-Pacific countries. Amendments were made where 
appropriate and the final questionnaire was activated online for six weeks from mid-May to early July 2017.

More than 20,000 communication professionals throughout Asia-Pacific were invited to participate via e-mails sent to a database provided by the Asia-Pacific Association of Communication Directors (APACD). Also, supporting professional associations in a number of countries sent invitations to their members. This provided a sampling frame restricted to professionals in the field, and the APACD list ensured that the views of experienced and senior professionals (i.e., directors and managers) were solicited.

A total of 3,647 participants started the survey. Incomplete surveys and responses from outside the sample were deleted from the dataset. This resulted in 1,306 fully completed responses from communication professionals in 22 Asia-Pacific countries, which was made up of all the major economies in the region in including China, India, Taiwan, Thailand, Indonesia, Japan, Korea, Vietnam, Australia, New Zealand, Hong Kong and Singapore.

\subsection{The sample}

Participants comprised communication professionals working in corporations, government, non-profit organizations, and communication agencies. Three out of four participants in the 2017/18 study are communication leaders, with 36.8 per cent holding a position as head of communication or CEO of a communication consultancy, and 35.6 per cent working as unit leaders or in charge of a single communication discipline in an organization. Participants are also quite experienced, with an average age of 45.0 years and 59.9 per cent having more than 10 years of experience in communication management. Reflecting 'feminization' of the PR field (Aldoory, 2007), 57.7 per cent of responses were from women and 42.3 per cent were from men.

Participants in the study are highly educated, with almost half (48.7 per cent) holding a Master's degree and 41.4 per cent holding a Bachelor's degree. A further 4.5 per cent hold a doctorate. One fifth of the participants (20.0 per cent) work in multinational organizations with their origin in Asia-Pacific. Another 26.6 per cent represent multinational organizations headquartered in another continent, while 43.7 per cent work in national or local organizations.

Almost three out of four practitioners participating in the study work in communication departments of organizations, with 29.6 per cent employed in joint stock (public) companies; 20.1 per cent in private companies, 12.6 per cent in government organizations; and 8.8 per cent in non-profit organizations, while 28.9 per cent are communication consultants working for agencies or freelance

\subsection{Data analysis}

The Statistical Package for the Social Sciences (SPSS) was used for data analysis. Results were tested statistically with, depending on the variable, Pearson's chi-square tests $\left(\chi^{2}\right)$, ANOVA/Scheffe post-hoc tests, Kendall rank correlation, and T-Tests. Results were classified as significant $(\mathrm{p} \leq 0.05)$ or highly significant $(\mathrm{p} \leq 0.01)$.

As well as collecting data on the demographics, role and experience of practitioners, their organizations' structure and areas of operation, and the performance and influence of communication departments, the survey explored practitioner roles and activities, issues and challenges faced, and practitioners' perception of their capabilities to address these roles, activities, issues and challenges. 


\section{Key findings: The rise and rise of digital and social media}

The survey found that more than 90 per cent of the communication practitioners in Asia-Pacific see social media and social networks as important channels for communication with stakeholders, gatekeepers and audiences. Their perceived importance has grown strongly since the previous APCM survey in 2015/16 when 75 per cent rated social media as important and when those channels were rated second behind traditional press and media relations with print newspapers or magazines.

While Valentini (2015) has questioned whether social media is "good" for public relations", the view of practitioners in Asia-Pacific in relation to RQ1 echoes the Global Alliance's (2017) finding that effectively using digital channels is among key capabilities required among communication professionals today and in the near future. It also reflects international research that shows digital and social media are changing the way practices such as public relations are conducted (Wright \& Hinson, 2017).

In comparison, media relations with print newspapers and magazines has slipped substantially from being the most important channel for communication with stakeholders and audiences (76.5 per cent rated this as important in 2015/16) to the eighth most important channel (61.5 per cent in 2017/18). The importance of television and radio journalists also has declined across the region to 67.0 per cent, except in the Philippines where 91.5 per cent of practitioners rated traditional broadcast media as important channels.

These trends are mostly consistent across the region, although print newspapers and magazines remain more important in Japan and India than in other countries. Japan is the only country in the region where print media are rated as more important than social media. Detailed comparison between countries was not possible because the sample sizes in a number were insufficient.

Looking forward to 2020, Asia-Pacific practitioners foresee further growth in digital communication including mobile and a further decline in the importance of print newspapers and magazines and also a significant decline in the use of television. The shift to digital and social media and mobile is equally pronounced in Europe (Zerfass, Moreno, Tench, Verčič, \& Verhoeven, 2017).

Furthermore, a new trend evident in marketing communication in particular is identification of the role and importance of social media influencers - people online who others follow and from whom they take a lead or advice in relation to buying products or services, identification of fashion trends, and even voting in elections. Examples are professional and part-time bloggers, activists and celebrity bloggers (Freberg, Graham, McGaughey, \& Freberg, 2011; Khamis et al., 2017). More than 70 per cent of communication practitioners in Asia-Pacific agree that social media influencers (SMIs) are important for their organizations' communication activities. However, less than half of the organizations have an approach or strategies in place to engage with those influencers.

Engagement with SMIs is seen as very important in China, Taiwan, Thailand, Indonesia, Japan and India although, surprisingly, this is not seen as having the same importance in Australia, New Zealand, Hong Kong and Singapore. Less than half of Australian practitioners see engagement with SMIs as important and less than 30 per cent have specific strategies for engaging SMIs, despite growing recognition of their influence. 
Given the identified importance of digital and social media as channels of communication, and the rise of social media influencers as important intermediaries in most countries, it could be expected that capabilities in these areas of practice would be high priorities among communication professionals and their organizations. However, the APCM found that this is not the case, instead identifying a major gap.

\section{Key findings: The gap in digital and social media capabilities}

Despite the recognized importance of social media, only a small proportion of communication practitioners in Asia-Pacific (7.7 per cent) report having 'very highly developed' capabilities in using these platforms. Based on ratings of 11 skill dimensions, the social media capabilities of 37.6 per cent of practitioners were self-assessed as 'highly developed'. However, 43.3 per cent reported having only 'moderate' capabilities and 11.4 per cent reported having 'low' or 'very low' capabilities in using these important channels. This is a concerning finding in relation to RQ2 (see Figure 2).

The highest scores for capabilities in social media were reported in Indonesia, China, Taiwan, Thailand, and Vietnam while, somewhat surprisingly, practitioners in Japan, Australia, and Hong Kong lag in social media proficiency, according to the survey. This is counter-intuitive and concerning given that these are highly developed countries. Also Australia reflects Western approaches to public relations and communication management, which means that these trends are likely to be similar in the USA, UK and Europe.

Figure 2. Overall level of capability in social media.

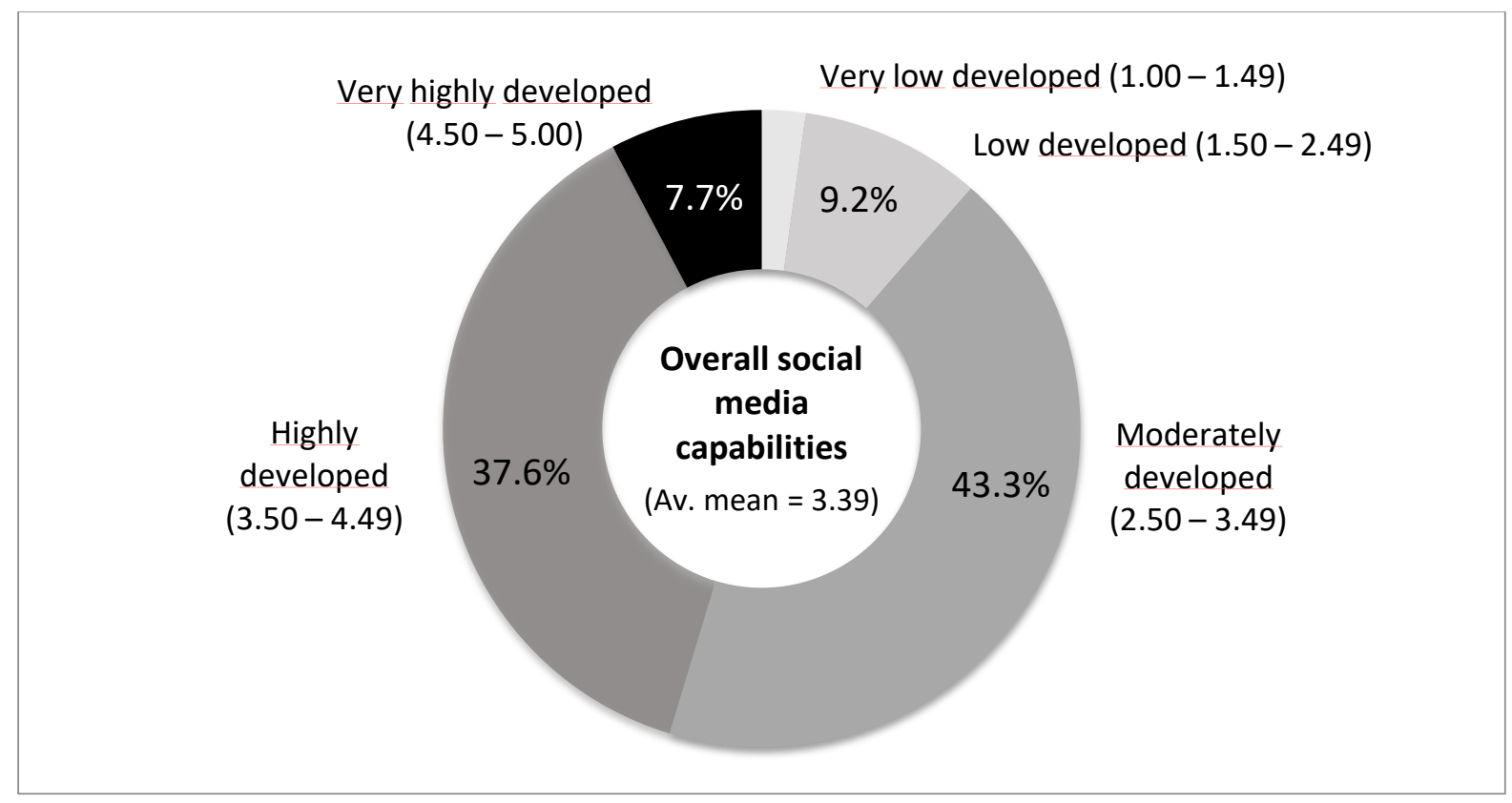

$n=1,306$ communication professionals from 22 countries. Q 5: How would you rate your personal capabilities in the following areas? Scale 1 (Very low) - 5 (Very high). Percentages based on categorized overall mean values for 11 items representing social media skills.

Practitioners reported that their highest level of capabilities is in 'delivering messages via social media'. This indicates a focus on one-way information transmission that is contrary to twoway models of communication advocated in PR excellence theory (Grunig et al., 2002) and contrary to dialogic theory (Kent \& Taylor, 2002; Taylor \& Kent, 2014) and interactive social media theory (Benkler, 2006; Curran, Fenton \& Freedman, 2012; Kent, 2013). Practitioners 
reported 'initiating web-based dialogues with stakeholders' among their lowest capabilities in social media. Furthermore, they reported moderately low capabilities in 'interpreting social media monitoring' (i.e., listening) and 'managing online communities' (engagement) and very low capabilities in 'understanding the use of algorithms' (see Figure 3). This further indicates that the focus of practitioners remains on technical skills and tasks, such as posting messages, requiring basic skills and competencies, and fails to address capabilities required to adapt to change and prepare for the future.

Figure 3. Level of capability in specific aspects of using social media.

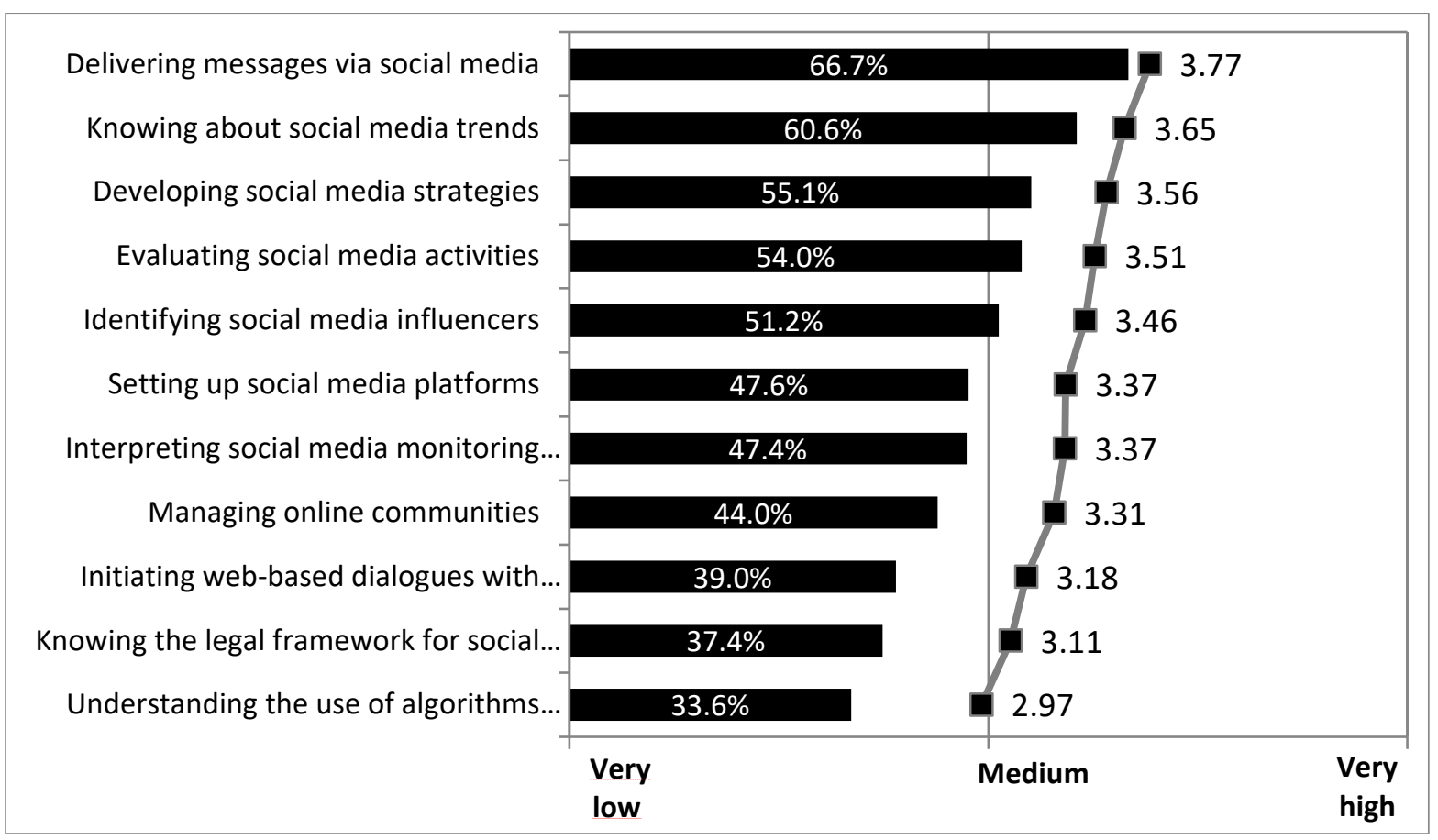

$n=1,306$ communication professionals from 22 countries. Q 5: How would you rate your personal capabilities in the following areas? Scale 1 (Very low) - 5 (Very high). Percentages: Frequencies based on scale points 4-5. Mean values.

Communication professionals in Asia-Pacific rate their skills in social media higher than do professionals in Europe and Latin America based on the comparable findings of Moreno, Molleda, Athaydes and Suarez (2017) and Zerfass et al. (2017) (see Figure 4). However, this finding is likely to be affected by variances inherent in self-reporting. Furthermore, it is hardly a positive finding because comparison only serves to show that skills and capabilities in social media use and management are low in a number of countries and that this is a key area for development internationally if digital and social media are important for PR and communication management. 
Figure 4. Comparison of social media skills among communication professionals in Asia-Pacific, Europe and Latin America.

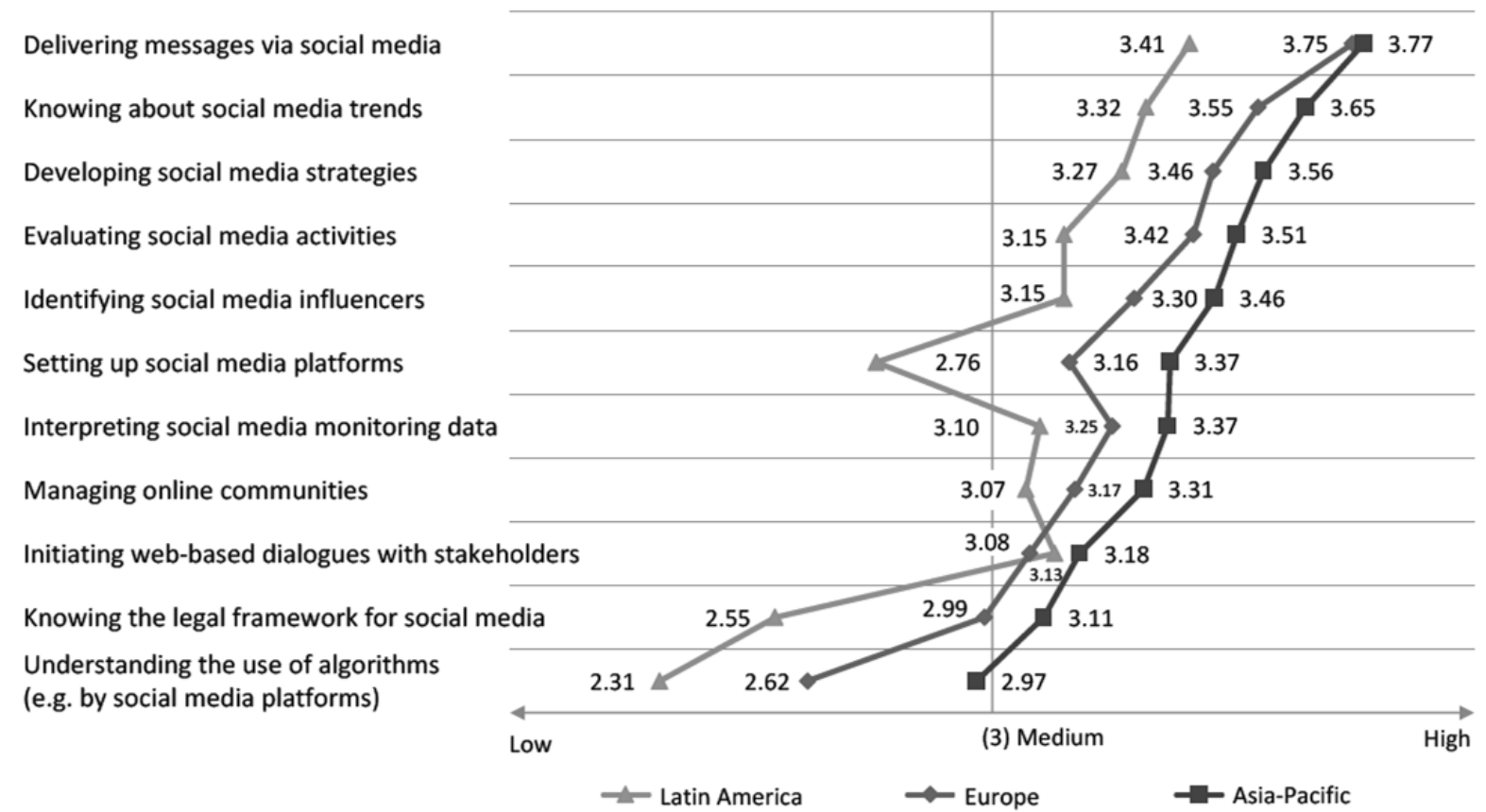

Global Communication Monitor 2017 data based on surveying $n \geq 4,893$ communication professionals in 82 countries (Zerfass et al., 2016, $n \geq 2,675$ professionals in Europe; Macnamara, Lwin, Adi, \& Zerfass, 2017, $n=$ 1,306 professionals in Asia-Pacific; Moreno et al., 2017, $n=912$ professionals in Latin America). Q 15/5/15: How would you rate your personal capabilities in the following areas? Scale 1 (Very low) - 5 (Very high). Mean values.

On a positive note in relation to RQ2, the 2017/18 Asia-Pacific study reported improvement in social media skills compared with the 2015/16 Asia-Pacific Communication Monitor (Macnamara, Lwin, Adi, \& Zerfass, 2015) - albeit only slightly in some key areas. For example, practitioners across the region rated themselves an average of 3.52 on a five-point scale for 'developing social media strategies' in 2015/16, which improved to an average score of 3.56 in 2017/18. However, this indicates a small improvement at best and in all likelihood is not statistically significant.

Of concern, however, is the finding that 66.7 per cent of practitioners in Asia-Pacific rated themselves highest for delivering messages via social media compared with knowing about social media trends (60.6 per cent), developing social media strategies (55.1 per cent), and evaluating social media (54.0 per cent). Only 39.0 per cent of practitioners rated 'initiating web-based dialogues with stakeholders' as a strength, with an average competency rating of 3.18 on a five-point Likert scale - i.e., just above average (see Figure 4).

This and the previous findings indicate that communication professionals continue to mostly use social media for one-way information transmission rather than fully utilizing the interactive capacity of these channels for two-way communication including listening - an approach that has been criticized by communication researchers and social media experts (Duhé \& Wright, 2013; Kent, 2013; Macnamara, 2014, 2016; Macnamara \& Zerfass, 2012). Thus, the potential of social media as platforms for dialogue and engagement as discussed by Taylor and Kent (2014), Gregory (2015), Macnamara (2016), Plowman and Wilson (2018), and others is not being achieved. This implications of this theory-practice gap and what it might mean for theory-building and practice will be examined in the following 'Discussion and conclusions' section. 
Also, practitioners acknowledge a lack of digital knowledge and skills more broadly, such as in digital analytics, the use of algorithms, and technologies associated with analysis of 'big data', revealing that capabilities in relation to digital technologies are an area for significant improvement.

A further related finding in the study in response to RQ3 indicates that this lack of capabilities will not be redressed without initiatives to expand education and training. Practitioners reported that training and development was not readily available to them in the areas of greatest need. For example, 64.2 per cent of practitioners in Asia-Pacific cited 'technical knowledge' overall as a need, but only 16.5 per cent said that training in this area was available in their organization. Similarly, almost 60 per cent (59.8 per cent) reported that they needed increased 'technical skills', particularly in relation to digital technologies, but only 20.8 per cent reported that technical training was available in their organization (see Figure 5).

Figure 5. Reported development needs of practitioners compared with availability of training and development.

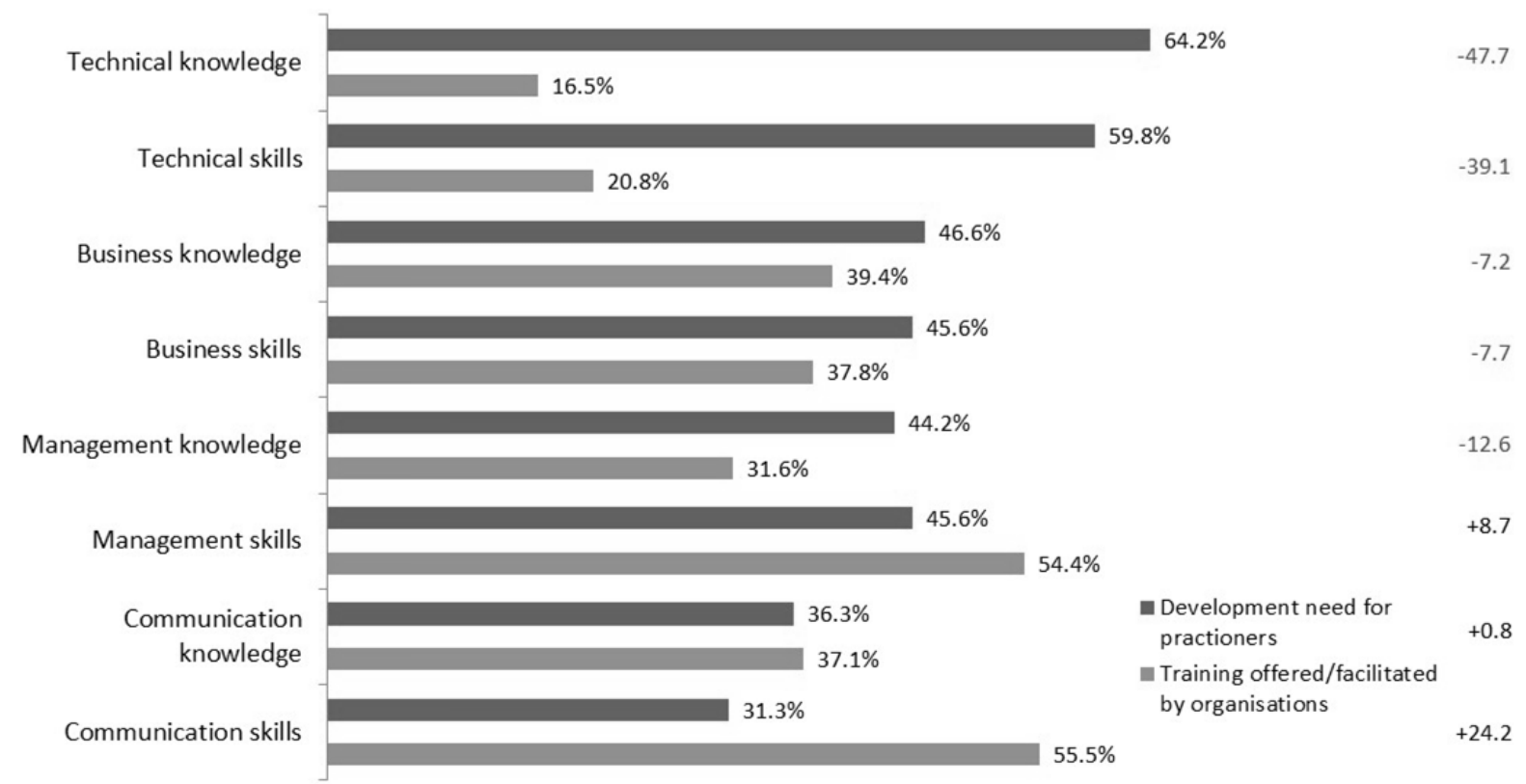

$n=1,306$ communication professionals from 22 countries. $Q$ 7: Thinking of yourself, your current capabilities and your future development, which of the following skills and knowledge areas do you believe are in need of developing? Scale 1 (No need to develop) - 5 (Strong need to develop). Percentages: Frequency based on scale points 4-5. Q 7 (continued): Does your organization already offer training programs in these fields? Percentages: Frequency based on selection of item.

Looking ahead, this suggests that postgraduate education can play a role by placing greater emphasis on how two-way communication, dialogue and relationship-building can be accomplished in a digital environment. Also, there are lessons for the industry. Communication industry bodies such as public relations institutes and associations should recognize a need and opportunity to provide increased professional development in relation to social media and digital communication technologies to meet the needs of the field today and in the future. In addition, employers need to provide increased training and development for their communication professionals if they are to fully take advantage of new communication technologies.

For researchers, these findings pose a challenge to identify the reasons for this gap in capabilities despite management focus on developing capabilities for the future and a widely 
reported focus among PR and communication practitioners on digital and social media. Researchers and theoreticians also need to explore solutions to this theory-practice gap. Some suggestions are put forward in the following.

\section{Discussion and conclusions}

The findings of the study show that, despite the recognized importance of digital platforms and social media, PR and communication practitioners have low to modest capabilities in using these media. With use of these channels forecast to grow rapidly over the next 5-10 years, this finding presents a challenge for educators, professional industry organizations, employers, and individual practitioners.

While learning to use digital platforms and social media competently and effectively presents an immediate challenge, the concerns raised by Valentini (2015) and recent analysis by Plowman and Wilson (2018) indicate that researchers and practitioners also need to apply critical thinking to claims and projections about the efficacy of social media and examine social media communication through the lens of strategic planning. As Plowman and Wilson (2018) found, based on a mixed-method study involving a survey and interviews with practitioners, social media use by PR and communication practitioners is predominantly tactical. Thisfinding is supported by the Asia-Pacific and European Communication Monitor studies that identified 'linking business strategy and communication' as the second highest rated issue of concern after 'coping with the digital evolution and social web' (Macnamara et al., 2017, p. 18; Zerfass et al. 2018, p. 44). With social media widely used for well over a decade ${ }^{3}$, the popularity and perceived importance of social media in PR and communication management practice in the absence of adequate capabilities suggests a Lemming-like approach to using social media, rather than a strategic approach supported by critical thinking and acquisition of a high level of capabilities.

This in turn raises broader, longer-term questions about how public relations and communication management engage with and adopt new technologies. Today, academic and industry conferences are abuzz with enthusiastic discussion of the use of algorithms, 'big data' analysis and AI (artificial intelligence) as the 'next big things'. A lesson from analysis of the adoption of social media and digital communication in the field is that PR and communication management need to avoid the traps of the technology hype cycle identified by Gartner (2018). Gartner's research has found that discussion and adoption of new technologies is typically characterized by hype that creates a "peak of inflated expectations", which needs to be overcome to progress to what the hype cycle refers to as the "slope of enlightenment" and the "plateau of productivity". This requires development of capabilities including critical thinking, adaptability, ongoing learning, and creativity and innovation..

On the face of it, the data suggest that educators need to ensure that the appropriate knowledge, skills and abilities (i.e., competencies) and capability development are incorporated in undergraduate and postgraduate courses. The identified gap in capabilities also highlights a challenge for industry organizations and service providers involved in professional development of communication practitioners. The APCM study suggests that the current generation of practitioners lack capabilities in one of the most important and fastest growing areas of communication practice. Without a program of continuing learning, corporate, government and organizational communication practitioners will be left behind and opportunities in the digital age are likely to be taken up by others such as digital and social media specialists. However, the implications and learnings from this research in response to RQ4 extend much further. 
While discussion of a 'theory-practice gap' may be seen as hackneyed, as it is lamented in many fields, the findings of this survey do show a significant gap between common practice in a rapidly developing region of the world and communication and public relations theory. Therefore, this gap needs further critical analysis. One response to this dichotomy is that practitioners need to better understand theory, which suggests that practitioners are at fault and that the solution is increased dissemination of existing theoretical knowledge. However, an alternative perspective that deserves to be further explored is whether the body of public relations theory is predominantly or overly normative and whether the field lacks practical theory.

Despite claims by its authors that Excellence theory is positive (explaining how public relations is practiced) as well as normative - how it should be practiced based on certain assumptions and values (Grunig et al., 2002, p. 310), critical theorists have argued that this substantial body of theory is normative and unachievable in the 'real world' (Leitch \& Neilson, 2001; L'Etang, 2008; Murphy, 1991; Pieczka, 2006). Also, given the apparently widespread failure to achieve dialogue and demonstrate principles of mutuality even in interactive social media, as discussed here and in other studies, critical thinking demands reflection on whether dialogic theory of public relations and other theories based on mutuality and relationships are normative and not practical theories in their current stage of development. In the very least, findings such as those of this study warrant increased focus on practical theory in public relations theory building.

While critical PR theorists have usefully focused attention on the limitations of normative theory and proposed a number of new paradigms and perspectives (Edwards \& Hodges, 2011; L'Etang, 2008; Pieczka, 2006), little public relations literature has addressed practical theory as it is defined and discussed by Craig (2018), Cronen (2001) and others such as Fuchs and Qiu (2018). As far back as Grunig and Hunt (1984), the term has been used, with these authors saying that "all the pieces for a comprehensive and practical theory of public relations exist" (1984, p. 77). Other literature also refers to "practical approaches" to public relations (Kent \& Taylor, 2002, p. 21) and "practical models" (Bowen, 2005). However, a search of public relations journals found no in-depth discussion of practical theory as distinct from discussion of practice and practical issues in public relations and as distinct from critical, positive and other types of theory.

A requirement and benefit of practical theory is to look beyond concepts, explanations and broad principles to identify specific principles and guidelines to operationalize the theory with a focus on change and improvement. The work of Craig (2018) and others (e. g., Fuchs \& Qiu, 2018), and the journey of communication studies as a discipline, can inform such an approach. As to whether further theory building is needed in public relations, Ferguson (2018) recently argued that there is a need to speed the development of theory in the field and this journal is committed to such a project.

Looking beyond the specific gap in relation to social media identified in the 2017/18 APCM and similar gaps identified in other studies in Europe and Latin America, the research literature indicates that PR and communication professionals need not only knowledge, skills, abilities and competence in relation to key activities today, but also capabilities in the broader sense. As identified in the literature reviewed in Section 2, capabilities refer to ongoing learning, adaptation, critical thinking, and creativity and innovation to meet continually changing environments and challenges. Specialist literature in the HR management and professional development fields that explicate the shift to capabilities rather than traditional competency models also offer tools to advance theory building in public relations, particularly practical theory. 
While the latest Global Alliance capabilities framework represents a step in this direction, PR and communication researchers, educators and industry leaders also need to look more broadly at technological change and other forms of disruptive change. Whereas employers and industry organizations have traditionally called for and in many cases continue to advocate technical skills and competencies as the core of PR and communication management education and training (e.g., Bates, 2015; CIPR, 2017), this analysis indicates that curricula and professional development programs need to increasingly include courses in creativity and innovation and alternative ways of thinking. This will require interdisciplinary engagement with the management, professional studies, and development scholarship identified, as well as with research and scholarship focused on coping with change based on, for example, adaptive systems (Morowitz \& Singer, 2018), emergent strategy (Mirabeau \& Maguire, 2014) and innovative ecosystems (Dedehayir, Ortt \& Seppänen, 2017).

Thus, as well as identifying a gap to be addressed in education and training, this analysis suggests two inter-related directions for future theory building in public relations and communication management: (1) increased focus on the development of practical theory and (2) increased interdisciplinary engagement with neighboring and complementary fields, such as those referred to in this analysis.

\section{Limitations and further research}

The APCM is based on self-reporting by practitioners in a survey. The longitudinal nature of the study is useful in tracking changes in practices and perceptions over time. However, further research using qualitative as well as quantitative methods to gain more in-depth data is important to gain further insights into the reasons for the gap in capabilities. Also, further critical analysis will be useful in exploring the potential for practical theory in public relations and communication management and the issues that such theory should address.

\section{Acknowledgements}

This research was conducted independently with support from Prime Research; Nanyang Technological University; RFI Asia; Communication Director magazine; the Asia-Pacific Association of Communication Directors (APACD); Quadriga University of Applied Sciences; and the European Public Relations Education and Research Association (EUPRERA).

\section{References}

Aldoory, L. (2007). Reconceiving gender for an 'excellent' future in public relations scholarship. In E. Toth (Ed.), The future of excellence in public relations and communication management (pp. 399-411). Mahwah, NJ: Lawrence Erlbaum Associates.

AMEC (Association for Measurement and Evaluation of Communication). (2017). AMEC global summit on measurement: Disruptive communication. London, UK: Author. Retrieved from http://amecglobalsummit.org

Bates, D. (2015, July 20). Writing skills are highest priority for new PR hires. Institute for Public Relations [Web log]. Retrieved from http://www.instituteforpr.org/writing-skills-highest-prioritynew-pr-hires

Benkler, Y. (2006). The wealth of networks: How social production transforms markets and freedom. New Haven, CT: Yale University Press.

Blakiston, R. (2011). Building knowledge, skills, and abilities: Continual learning in the new information landscape. Journal of Library Administration, 51(7-8), 728-743.

https://doi.org/10.1080/01930826.2011.601272

Botan, C., \& Hazleton, V. (Eds.). (2006). Public relations theory II. Mahwah, NJ: Lawrence Erlbaum. 
Bowen, S. (2005). A practical model for ethical decision making in issues management in public relations. Journal of Public Relations Research, 17(3), 191-216. https://doi.org/10.1207/s1532754xjprr1703_1

Broom, G., \& Dozier, D. (1990) Using research in public relations: Applications to program management. Englewood Cliffs, NJ: Prentice-Hall.

Cairns, L. (2000, April). The process/outcome approach to becoming a capable organization. Paper presented to Australia Capability Network Conference, Sydney.

Caldwell, R., (2008). HR business partner competency models: Re-contextualizing effectiveness. Human Resource Management Journal, 18(3), 275-294. https://doi.org/10.1111/j.17488583.2008.00071.x

CBRE. (2015). Fast forward 2030: The future of work and the workplace. Los Angeles, CA: Author. Retrieved from http://www.cbre.com/Research-Reports/Future-of-Work

Cetin, G., Demirçiftçi, T., \& Bilgihan, A. (2016). Meeting revenue management challenges: Knowledge, skills, and abilities. International Journal of Hospitality Management, 57, 132-142. https://doi.org/10.1016/j.ijhm.2016.06.008

CIPR (Chartered Institute of Public Relations). (2015). State of the profession 2015. Retrieved from https://www.cipr.co.uk/content/policy-resources/research/our-research-and-reports/cipr-stateprofession-2015

CIPR (Chartered Institute of Public Relations). (2017). State of PR 2017. Retrieved from https://www.cipr.co.uk/sites/default/files/10911_State\%20of\%20PR\%202017_f1.pdf

COMPRED (Commission of Public Relations Education). (2006). The professional bond. Retrieved from http://www.commpred.org/_uploads/report2-full.pdf

COMPRED (Commission on Public Relations Education). (2012). Educating for complexity: Standards for a Master's degree in public relations. Retrieved from https://www.commpred.org/_uploads/report5-full.pdf

COMPRED (Commission on Public Relations Education). (2018). Fast forward: Foundations + future state. Educators + practitioners. Retrieved from http://www.commissionpred.org/wpcontent/uploads/2018/04/report6-full.pdf

Craig, R. (2018). For a practical discipline. Journal of Communication, 68(2), 289-297. https://doi.org/10.1093/joc/jqx013

Cronen, V. (2001). Practical theory, practical art, and the pragmatic-systemic account of inquiry. Communication Theory, 11(1), 14-35. https://doi.org/10.1111/j.1468-2885.2001.tb00231.x

Curran, J., Fenton, N., \& Freedman, D. (2012). Misunderstanding the internet. New York, NY: Routledge.

Dalkey, N. \& Helmer, O. (1963). An experimental application of the Delphi method to the use of experts. Management Science, 9(3), 458-467.

Dedehayir, O., Ortt, R., \& Seppänen, M. (2017). Disruptive change and the reconfiguration of innovation ecosystems. Journal of Technology Management and Innovation, 12(3), 9-20.

Department of Veterans Affairs. (2009). What are KSAs? Retrieved from https://www.va.gov/jobs/hiring/apply/ksa.asp

Duhé, S., \& Wright, D. (2013). Symmetry, social media, and the enduring imperative of two-way communication. In K Sriramesh, A. Zerfass \& J. Kim (Eds), Public relations and communication management: Current trends and emerging topics (pp. 93-107). New York, NY: Routledge.

Edwards, L. (2018). Understanding public relations: Theory, culture and society. London, UK: Sage.

Edwards, L., \& Hodges, C, (Eds.) (2011) Public relations, society and culture: Theoretical and empirical explorations. Abingdon, UK: Routledge.

Fraser, S., \& Greenhalgh, T. (2001). Coping with complexity: Educating for capability. British Medical Journal, 323(7317), 799-803. https://doi.org/10.1136/bmj.323.7316.799

Ferguson, M. (2018). Building theory in public relations: Interorganizational relationships as a public relations paradigm. Journal of Public Relations Research. Advance online publication. https://doi.org/10.1080/1062726X.2018.1514810

Freberg, K., Graham, K., McGaughey, K., \& Freberg, L. (2011). Who are the social media influencers? A study of public perceptions of personality. Public Relations Review, 37(1), 90-92. https://doi.org/10.1016/j.pubrev.2010.11.001

Freeman, R. (1984). Strategic management: A stakeholder approach. London, UK: Pitman. 
Frey, T. (2014, March 21). 162 future jobs: Preparing for jobs that don’t yet exist. Retrieved from http://www.futuristspeaker.com/business-trends/162-future-jobs-preparing-for-jobs-that-dont-yetexist

Fuchs, C., \& Qiu, J. (2018). Ferments in the field: Introductory reflections on the past, present and future of communication studies. Journal of Communication, 68(1), 219-232. https://doi.org/10.1093/joc/jqy008

Gardner, A., Hase, S., Gardner, G., Dunn, S., \& Carryer, J. (2008). From competence to capability: A study of nurse practitioners in clinical practice. Journal of Clinical Nursing, 17(2), 250-258.

Gartner, Inc. (2018). Gartner hype cycle. Retrieved from https://www.gartner.com/technology/research/methodologies/hype-cycle.jsp

Global Alliance (for Public Relations and Communication Management). (2015, July). The global body of knowledge (GBOK) project: The standard” to practice public relations and communication management. Retrieved from https://static1.squarespace.com/static/561d0274e4b0601b7c814ca9/t/56c1faea59827e4bccf4daf2/1 455553260847/GBOK2015.pdf

Global Alliance for Public Relations and Communication Management. (2018). A global capabilities framework for the public relations and communication management profession. Lugano, Switzerland. Retrieved from https://www.globalalliancepr.org/capabilitiesframeworks

Gregory, A. (2015). Practitioner-leaders' representation of roles: The Melbourne Mandate. Public Relations Review, 41(5), 598-606. https://doi.org/10.1016/j.pubrev.2014.02.030

Grunig, L., Grunig J., \& Dozier D. (2002). Excellent organizations and effective organizations: A study of communication management in three countries. Mahwah, NJ: Lawrence Erlbaum.

Hase, S., \& Davis, L. (1999, August). From competence to capability: The implications for human resource development and management. Paper presented to the 17th Annual conference of the Association of International Management, San Diego, CA.

Holtzhausen, D., \& Zerfass, A. (2013). Strategic Communication - Pillars and perspectives of an alternative paradigm. In A. Zerfass, L. Rademacher, \& S. Wehmeier (Eds.), Organisationskommunikation und public relations: Forschungsparadigmen und neue Perspektiven (pp. 73-94). Weisbaden, Germany: Springer.

International Standards Organization. (2012, November 15). Getting the best out of people: ISO 10018 aids ISO 9001 implementation. Retrieved from https://www.iso.org/news/2012/11/Ref1679.html

Johnston, K. (2014). Public relations and engagement: Theoretical imperatives of a multidimensional concept. Journal of Public Relations Research, 26(5), 381-383. https://doi.org/10.1080/1062726X.2014.959863

Kent, M. (2013). Using social media dialogically: Public relations role in reviving democracy. Public Relations Review, 39, 337-345. https://doi.org/10.1016/j.pubrev.2013.07.024

Kent, M., \& Taylor, M. (2002). Toward a dialogic theory of public relations. Public Relations Review, 28(1), 21-37. https://doi.org/10.1016/S0363-8111(02)00108-X

Khamis, S., Ang, L., \& Welling, R. (2017). Self-branding, 'micro-celebrity' and the rise of social media influencers. Celebrity Studies, 8(2), 191-208. https://doi.org/10.1080/19392397.2016.1218292

Kiesenbauer, J. (2018). Kompetenzmanagement für die Unternehmenskommunikation [Competency management for corporate communications]. Wiesbaden, Germany: Springer VS.

Leitch, S., \& Neilson, D. (2001). Bringing publics into public relations: New theoretical frameworks for practice. In R. Heath (Ed.), Handbook of public relations (pp. 127-138). Thousand Oaks, CA: Sage.

Lester, S. (1995). Beyond knowledge and competence towards a framework for professional education. Capability, 1(3), 44-52.

Lester, S. (2013). Professional competence standards and frameworks in the UK. Assessment and Evaluation in Higher Education, 39(1), 38-52. https://doi.org/10.1080/02602938.2013.792106

Lester, S. (2014). Professional standards, competence and capability. Higher Education, Skills and Work-based Learning, 4(1), 31-43. https://doi.org/10.1108/HESWBL-04-2013-0005

Lester, S. (2016). Communicating professional competence. London, UK: Erasmus+ programme of the EU.

L’Etang, J. (2008). Public relations: Concepts, practice and critique. London, UK: Sage. 
Littlejohn, S., Foss, K., \& Oetzel, J. (2017). Theories of human communication (11th ed.). Long Grove, IL: Waveland.

Macnamara, J. (2014). The 21st century media (r)evolution: Emergent communication practices. New York, NY: Peter Lang.

Macnamara, J. (2016). Organizational listening: The missing essential in public communication. New York, NY: Peter Lang.

Macnamara, J., Lwin, M., Adi, A., \& Zerfass, A. (2015), Asia Pacific Communication Monitor 2015/16: The state of strategic communication and public relations in a region of rapid growth. Survey results from 23 countries. Hong Kong: APACD. Retrieved from http://www.communicationmonitor.asia

Macnamara, J., Lwin, M., Adi, A., \& Zerfass, A. (2017). Asia-Pacific Communication Monitor 2017/18: Strategic challenges, social media and professional competencies - Results of a survey in 22 countries, Asia-Pacific Association of Communication Directors, Hong Kong. Retrieved from http://www.communicationmonitor.asia

Macnamara, J., \& Zerfass, A. (2012). Social media communication in organisations: The challenges of balancing openness, strategy and management', International Journal of Strategic Communication, 6(4), 287-308. http://dx.doi.org/10.1080/1553118X.2012.711402

Mirabeau, L., \& Maguire, S. (2014). From autonomous strategic behaviour to emergent strategy. Strategic Management Journal, 35(8), 1202-1229. https://doi.org/10.1002/smj.2149

Moreno, A., Molleda, J., Athaydes, A. \& Suarez, A. (2017). Latin American Communication Monitor 2016-2017. Tendencias en comunicación estratégica: big data, automatización, engagement, influencers, couching y competencias. Resultados de una encuesta en 17 países. Madrid, Spain: DIRCOM/EUPRERA.

Morowitz, H., \& Singer, J. (2018). The mind, the brain and complex adaptive systems. New York, NY: Routledge.

Murphy, P. (1991). Limits of symmetry. In J. Grunig \& L. Grunig (Eds.), Public relations research annual, Vol. 3 (pp. 115-131). Hillsdale, NJ: Lawrence Erlbaum.

Nagarajan, R., \& Prabhu, R. (2015). Competence and capability: A new look. International Journal of Management, 6(6), 7-11.

Nussbaum, M. (2000). Women and human development: The capabilities approach. Cambridge; New York, NY: Cambridge University Press.

O’Connell, J., Gardner, G., Coyer, F., Gardner, G., \& Coyer, F. (2014). Beyond competencies: Using a capability framework in developing practice standards for advanced practice nursing. Journal of Advanced Nursing, 70(12), 2728-2735. https://doi.org/10.1111/jan.12475

Pieczka, M. (2006). Paradigms, systems theory and public relations. In J. L’Etang \& M. Pieczka (Eds.), Public relations: Critical debates and contemporary practice (pp. 331-358). Mahwah, NJ: Lawrence Erlbaum.

Plowman, K., \& Wilson, C. (2018). Strategy and tactics in strategic communication: Examining their intersection with social media use. International Journal of Strategic Communication, 12(2). 125144. https://doi.org/10.1080/1553118X.2018.1428979

Prestwich, R., \& Ho-Kim, T. (2007). Knowledge, skills and abilities of international business majors. Journal of Teaching and International Business, 19(1), 29-55. https://doi.org/10.1300/J066v19n01_03

PRIA (Public Relations Institute of Australia). (2015, November 14). Professional framework. Retrieved from https://www.pria.com.au/resources/pria-professional-framework

Sen, A. (1999). Development as freedom. New York, NY: Knopf.

Stevens, G. (2013). A critical review of the science and practice of competency modelling. Human Resource and Development Review, 12(1), 86-107. https://doi.org/10.1177/1534484312456690

Taylor, M., \& Kent, M. (2014). Dialogic engagement: Clarifying foundational concepts. Journal of Public Relations Research, 26(5), 384-398. https://doi.org/10.1080/1062726X.2014.956106

Tench, R., \& Moreno, A. (2015). Mapping communication management competencies for European practitioners: ECOPSI an EU study. Journal of Communication Management, 19(1), 39-61. https://doi.org/10.1108/JCOM-11-2013-0078

Teodorescu, T. (2006). Competence versus competency: What is the difference? Performance Improvement, 45(10), 27-30.

USA Jobs. (2018). What are KSAs? Retrieved from https://www.usajobs.gov/Help/faq/jobannouncement/KSAs 
Valentini, C. (2015). Is using social media "good” for the public relations profession? A critical reflection. Public Relations Review, 41(2), 170-177.

Verčič, D. (2008). Co-orientation model of public relations. In W. Donsbach (Ed.), The international encyclopedia of communication, Vol. III (pp. 995-998). Malden, MA: Blackwell.

Wright, D., \& Hinson, M. (2017). Tracking how social and other digital media are being used in public relations practice: A twelve-year study. Public Relations Journal, 11(1), 1-30.

Zerfass, A., Moreno, A., Tench, R., Verčič, D., \& Verhoeven, P. (2017). European Communication Monitor 2017. How strategic communication deals with the challenges of visualization, social bots and hypermodernity. Results of a survey in 50 Countries. Brussels: EACD, EUPRERA and Quadriga Media Berlin.

Zerfass, A., Verhoeven, P., Moreno, A., Tench, R. \& Verčič, D. (2016). European communication monitor 2016: Exploring trends in big data, stakeholder engagement and strategic communication. Results of a survey in 43 countries. Brussels, Belgium: EACD, EUPRERA and Quadriga Media Berlin.

Zerfass, A., \& Volk, S. (in print). Aligning and linking communication with organizational goals. In V. Luoma-aho \& M. Canel (Eds.), Handbook of public sector communication. London, UK: Wiley-Blackwell.

\section{Reference:}

Macnamara, J., Zerfass, A., Adi, A., \& Lwin, M. (2018). Capabilities of PR professionals for key activities lag: Asia-Pacific study shows theory and practice gaps. Public Relations Review.

https://doi.org/10.1016/i.pubrev.2018.10.010

1 Skills and capabilities are also addressed to some extent in human relations literature, which has distinct differences from human resources (HR) thinking. However, most research in relation to skills and capabilities of employees exists in HR literature focussed on training and development.

2 Valentini (2015) mainly questioned the "uncritical” use of social media in public relations and critiqued the use of social media in place of interpersonal communication.

3 Major social media sites such as Facebook, Twitter and YouTube were launched publicly between 2004 and 2006. 